\title{
A Body Condition Index Based on Body Mass and External Measurements of Live Leach's Storm-petrels.
}

\author{
Yasuaki NiIZUMA ${ }^{1 * * *}$, Akinori TAKAHASHI ${ }^{2 * * *}$, \\ Norio TOKITA ${ }^{3}$ and Shin-ichi HAYAMA ${ }^{4}$ \\ 1 Laboratory of Applied Zoology, Faculty of Agriculture, Hokkaido University. Kita-9, \\ Nishi-9, Kita-ku, Sapporo 060-8589, Japan and Institute of Low Temperature Science, \\ Hokkaido University. Kita-19, Nishi-8, Kita-ku, Sapporo 060-0819, Japan \\ 2 Akkeshi Marine Biological Station, Faculty of Science, Hokkaido University. Aikappu, \\ Akkeshi 088-1113, Japan. \\ 3 Division of Animal Nutrition, Nippon Veterinary and Animal Science University. \\ 1-7-1, Kyounan-cho, Musashino, Tokyo 180-8602, Japan \\ 4 Division of Wild Animal Medicine, Nippon Veterinary and Animal Science \\ University. 1-7-1, Kyounan-cho, Musashino, Tokyo 180-8602, Japan
}

An index of body condition was calculated as the residual from the regression of the cubed root of body mass against the first principle component score of a principle component analysis of six external measurements, which was represented as total body size. This index was called the residual body condition index, or RBCI. To evaluate the utility of the RBCI in studies of Leach's Storm-petrels (Oceanodroma leucorhoa), the RBCI was compared to measurements of total lipid mass. Total lipid content was extracted using ethyl-ether after birds had been killed under anesthesia. The RBCI explained $57.4 \%$ of the variation of the cubed root of total lipid mass. We could thus reasonably estimate the body condition of the parents breeding under natural conditions by measuring their body mass and external measurements.

Key Words: Body condition, Fasting phase, Leach's Storm-petrel, Total lipid mass

The extent of fat reserves is one of the most important factors that determines the reproductive output of birds (Chastel et al. 1995, Erikstad et al. 1997, Tveraa et al. 1998), making measurement of the lipid reserves of live birds highly desirable for ecological studies (Brown 1996). Recently, many investigators have used an index of body condition calculated from body mass and external measurements (e.g. head, wing, and tarsus length), in studies of a wide range of avian species (e.g. Bortolotti \& Iko 1992, Chastel et al. 1995, Takahashi et al. 1999). In this index, the total body size of individual birds is presumed to be represented by a first principal component score (PC1 score) of a principal component analysis of several external measurements. Furthermore, the lipid mass of individual birds is presumed to be equivalent to the residual from the regression line of body mass against the PC1 score (called the resid-

* Corresponding author, E-mail: niizuma@hnf.affrc.go.jp

** Present address: Japan Science and Technology Corporation, Hokkaido National Fisheries Research Institute, Fisheries Agency, Katsurakoi 116, 085-0802, Japan.

*** Present address: Department of Polar Science, School of Mathematical and Physical Science, The Graduate University for Advanced Studies. 1-9-10 Kaga, Itabashi-ku, Tokyo 173-8515, Japan 
ual body condition index or RBCI). The first assumption relating to the index, has been widely verified already (see Freeman \& Jackson 1990). The second assumption has not so far been examined, because validating it requires sacrificing birds and the process of lipid extraction from specimens using solvents is time consuming.

Leach's Storm-petrels (Oceanodroma leucorhoa) are among the smallest nocturnal Procellariiformes. Their body mass is highly variable in relation to breeding status. In this paper, we described the utility of the RBCI for the study of breeding Stormpetrels.

\section{MATERIAL AND METHODS}

\section{1) Specimens}

Leach's Storm-petrels were collected on Daikoku-jima (Daikoku Island; $42^{\circ} 52^{\prime} \mathrm{N}$, $144^{\circ} 52^{\prime} \mathrm{E}$ ), off east Hokkaido, Japan between April and August 1995. The island has sloping, grass-covered plains in which the Storm-petrels excavate their nest burrows. They breed across almost the entire island. The breeding population of Daikokujima was estimated to be about 584,000 pairs in 1993-1994 (Niizuma 1995).

A total of 60 birds were trapped and killed under total anesthesia with the permission of the Minister of the Environment (permission No. 123). The birds were captured in their nest burrows while they were engaged in incubating eggs or provisioning offspring with food. Thirty-eight of the 60 birds were killed immediately on capture. Nine incubating birds, and 13 birds rearing chicks, were killed after completion of a three day experimental fast.

In order to examine their physiological adaptation to fasting during incubation, these birds were kept in a small dark box without food for three days. In the wild, Storm-petrels regularly fast for three days during incubation, but they do not fast during the chick-rearing period. To allow comparison with incubating birds, birds rearing chicks were forced to fast. Nine incubating and 38 killed birds were defined as normally fasting birds and 13 birds rearing chicks were defined as forced fasting birds. All specimens were weighed and then stored at $-20^{\circ} \mathrm{C}$ until body composition analysis.

\section{2) External measurements}

External measurements were made after frozen specimens had been thawed. Wing length was measured to the nearest $1 \mathrm{~mm}$ using a stopped ruler, and maximum tail length, minimum tail length, culmen length, bill depth, and tarsus length were all measured to the nearest $0.05 \mathrm{~mm}$ using vernier calipers (see Niizuma et al. 1998 for details).

\section{3) Body compositions}

Each frozen specimen was thawed, then and weighed both before and after plucking. Feather mass was defined as the difference between the two weights. The contents of the digestive tracts were removed. Body mass (BM) was defined as the mass of a bird after removal of all ingesta. Carcass mass was defined as body mass minus feathers. For body composition analysis, defeathered carcasses were minced then airdried to a constant mass at $60^{\circ} \mathrm{C}$ for 36 hours. Water content was defined as the difference between the original mass and the final mass of the samples. Ash was weighed after combustion in a muffle furnace at 600 - $\mathrm{C}$ for three hours. Total lipid content was extracted using ethyl-ether in an ex-fat apparatus (Laboman GENECO, Nippon General Co., Ltd.). Protein mass was calculated by subtracting the lipid and ash masses from the dry mass. Carbohydrate content was not analyzed in this study because it represents less than $1 \%$ of body mass (Schmidt-Nielsen 1990). 
Table 1. Mass of body components in the normal and forced fasting birds. Means are given with $\pm \mathrm{SD}$. All seven masses are in grams.

\begin{tabular}{lcccc}
\hline & $\begin{array}{c}\text { Normal fasting birds } \\
(\mathrm{n}=47)\end{array}$ & $\begin{array}{c}\text { Forced fasting birds } \\
(\mathrm{n}=13)\end{array}$ & $t_{58}$ & p-values \\
\hline Body mass & $41.43 \pm 4.78$ & $31.54 \pm 1.48$ & 7.32 & $<0.0001$ \\
Carcass mass & $34.86 \pm 4.54$ & $25.15 \pm 1.11$ & 7.60 & $<0.0001$ \\
Feathers mass & $6.57 \pm 0.76$ & $6.39 \pm 1.47$ & 0.61 & $n . s$. \\
Water mass & $22.52 \pm 3.04$ & $16.73 \pm 1.63$ & 6.57 & $<0.0001$ \\
Protein mass & $6.89 \pm 1.18$ & $5.70 \pm 0.86$ & 3.39 & $<0.01$ \\
Lipid mass & $3.86 \pm 1.64$ & $1.21 \pm 0.92$ & 5.58 & $<0.0001$ \\
Ash mass & $1.59 \pm 0.22$ & $1.51 \pm 0.29$ & 0.75 & n.s. \\
\hline
\end{tabular}

\section{4) Residual body condition index}

Principal component analysis was used with the Pearson correlation matrix on the six external measurements to establish a total body size for all specimens (Freeman \& Jackson 1990) and PC1 scores were calculated for each sample. Masses were transformed to cubed roots (Mass ${ }^{1 / 3}$ ) to give the $\mathrm{PC} 1$ scores equivalent dimensions. $\mathrm{BM}^{1 / 3}$ was regressed upon the PC1 score in order to calculate the residual, which was RBCI. RBCI was compared to total lipid mass ${ }^{1 / 3}$ by using linear regression. Differences between means were tested using Student's t-test.

\section{RESULTS AND DISCUSSION}

1) Body composition in normal and forced fasting birds

Body and carcass masses were significantly greater in naturally fasting birds than in forced fasting birds (Table 1). Feather mass did not differ significantly between the two groups. Water, protein, and lipid masses were significantly greater in the naturally fasting birds than in forced fasting ones, however, there was no difference in ash mass between the two groups.

The loss of both lipid and protein by the forced fasting birds indicates that it is meaningless to estimate body conditions using lipid stores alone due to changes in fasting phases because the physiological character of a bird changes over the course of a fast (Cherel et al. 1988). Birds use carbohydrates and lipids as metabolic fuels in the early phases of fasting (regular fasting phase), but use protein in the later phase (critical fasting phase) once most lipids have been exhausted.

The birds forced to fast only had $31.3 \%$ of the lipid, $74.3 \%$ of the water, $82.7 \%$ of the protein, and $95.0 \%$ of the ash content of the normally fasting birds. Thus, over the course of the experimental fast, the birds consumed lipid, water, and protein, while they did not use ash as metabolic fuels. Lipid and protein are both used as metabolic fuels, while water is lost during consumption of lipid reserves and also by evaporation and respiration (Cherel et al. 1993). These results indicate that the birds forced to fast enter the critical fasting phase (Cherel et al. 1988). In contrast, the normal fasting birds had an average of $3.86 \mathrm{~g}$ of lipid. This is equivalent to 3.2 days of metabolic fuels since incubating Storm-petrels consume $1.2 \mathrm{~g}$ lipid per day while in their nesting burrows (Niizuma et al. 1999). It is known that parental birds abandon breeding if they reach the critical fasting phase (Ancel et al. 1997, Ancel et al. 1998). Birds 
Table 2. Principal component analysis for six external measurements. The first principal components (PC1) had a loading on each of the independent variables.

\begin{tabular}{lc}
\hline \multicolumn{1}{c}{ External measurements } & PC1 \\
\hline Wing length & 0.385 \\
Maximum tail length & 0.860 \\
Minimum tail length & 0.824 \\
Culmen & 0.224 \\
Bill depth & 0.383 \\
Tarsus length & 0.354 \\
\hline
\end{tabular}

breeding under natural conditions would always be in the regular fasting phase and such birds store some lipid reserves (Cherel et al. 1988).

Thus, an estimate of the mass of the lipid reserves of birds in the regular fasting phases would be a fair index of body condition, whereas the lipid reserves of birds in the critical fasting phase would be overestimated because these reserves are used (Massemin et al. 1997).

\section{2) Validity of the residual body condition index}

The residual body condition index was validated only for normally fasting Stormpetrels. The first principal component explained $31.5 \%$ of the variance in the entire data set of external measurements. The first principal component had a loading on each of the independent variables, ranging from 0.224 to 0.860 (Table 2). There was no difference in PC1 scores between the normal $(0.03 \pm 1.40)$ and forced fasting birds (-0.11 $\pm 1.40, t_{58}=0.31, n . s$.), indicating that body size was similar between the two groups.

There was a significant correlation between the PC1 score and ash mass ${ }^{1 / 3}$ in the normally fasting birds (ash mass ${ }^{1 / 3}=1.16+$ $0.02 \times \mathrm{PC} 1$ score, $r^{2}=0.30, \quad F_{1,45}=19.13, \quad p$ $<0.0001$, Fig. 1), indicating that the $\mathrm{PC} 1$ score can be used to represent the total body size of individual birds. When $\mathrm{BM}^{1 / 3}$ was plotted against PC1 score, and the regression line fitted, the RBCI could be obtained from the regression line $\left(r^{2}=0.002, F\right.$ ${ }_{1,45}=0.11$, n.s., Fig. 2). Total lipid mass ${ }^{1 / 3}$ was significantly dependent on the RBCI (total lipid mass $^{1 / 3}=1.53+1.39 \times$ RBCI, $r^{2}=0.57, F$ ${ }_{1,45}=60.65, p<0.0001$, Fig. 3).

The body size of a vertebrate is dependent to some extent on its skeletal structure. Calcium is important constituent of the skeleton and about $99 \%$ of total body calcium is found in the skeleton (McDonald $e t$ al. 1995). The significant correlation between the cubed root of the ash mass and the PC1 score, indicates that total body size can be represented by the PC1 score (Freeman \& Jackson 1990). While fasting, birds lose body mass mainly by consuming lipid and water as shown in this and in previous studies (e.g. Cherel et al. 1988). However, the skeletal structure does not vary during fasting, thus the $\mathrm{RBCI}$ is equivalent to the lipid reserves (Fig. 3). In conclusion, RBCI is a reliable index for estimating total lipid mass of birds breeding under natural condition with minimum disturbance.

We thank the Kasajima family for their great kindness during the field study. We are also grateful to H. Mukai, M. Moroi, S. Hamano, S. 


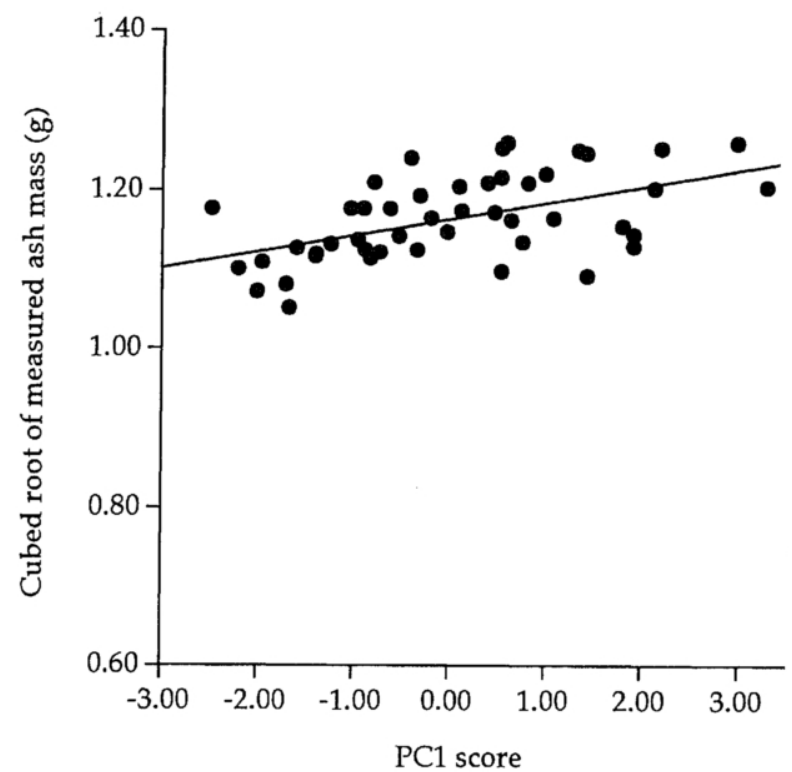

Fig. 1. The cubed root of ash mass as a function of the PC1 score extracted from principal component analysis of six external measurements of Leach's Storm-petrel. Regression line was that ash mass $^{1 / 3}=1.16+0.02 \times \mathrm{PC} 1$ score.

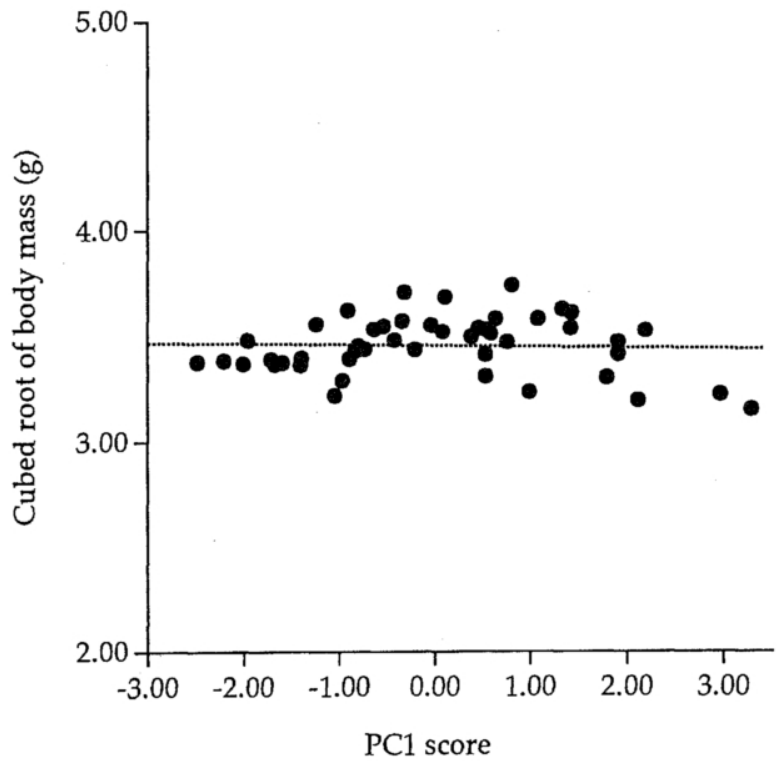

Fig. 2. $\mathrm{BM}^{1 / 3}$ plotted against $\mathrm{PC} 1$ score. The dashed line was calculated when $\mathrm{BM}^{1 / 3}$ was regressed upon $\mathrm{PC} 1$ score $\left(\mathrm{BM}^{1 / 3}=3.46+0.002 \times \mathrm{PC} 1\right.$ score $)$, although this regression line was not significant. 


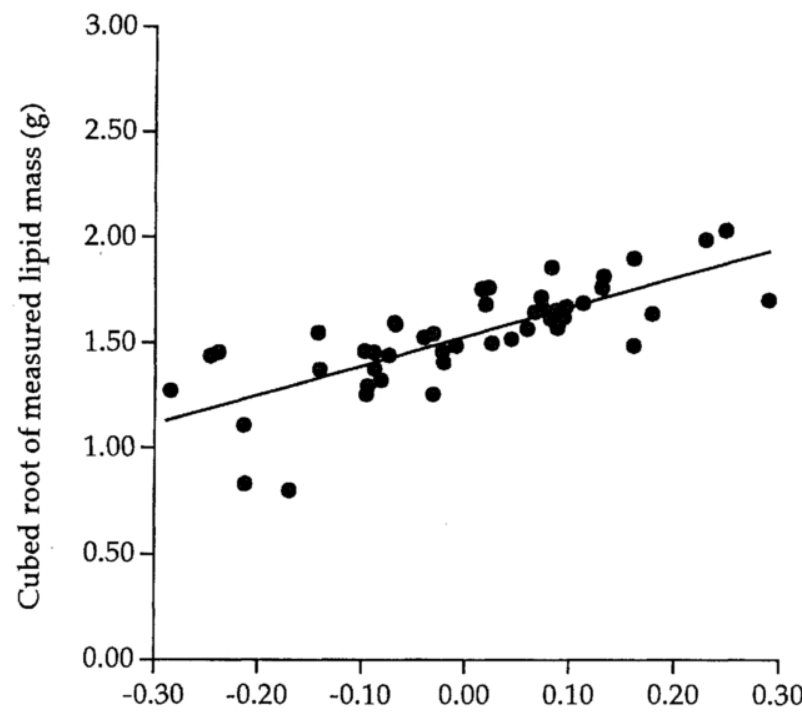

Residual body condition indices

Fig. 3. The cubed root of total lipid mass as a function of the residual body condition index of Leach's Storm-petrel. After carrying out regression analysis, the cubed root of body mass depended on PC1 scores. Regression line was that total lipid mass ${ }^{1 / 3}=1.53+1$. $39 \times \mathrm{RBCI}$.

Maekawa, Y. Matsumoto, K. Hamamoto, and M. Sawada for their logistical support during the course of this study. Students of Nippon Veterinary and Animal Science University assisted our laboratory work. K. Ishikawa and M. Chochi are also thanked for their comments on the early draft of manuscript. Drs. Y. Watanuki and R. P. Wilson made helpful comments on the manuscript and kindly improved the English, as did two anonymous reviewers. Permission to study seabirds on Daikoku Island was kindly give by the Ministers of the Environment and the Education.

\section{LITERATURE CITED}

Ancel, A., Petter, L. \& Groscolas, R., 1998. Changes in egg and body temperature indicate triggering of egg desertion at a body mass threshold in fasting incubating blue petrels (Halobaena caerulea). J. Comp. Phys. B 168: 533-539.

Ancel, A., Visser, H., Handrich, Y., Masman, D. \& Le Maho, Y., 1997. Energy saving in huddling penguins. Nature 385: 304-305.
Bortolotti, G. R. \& Iko. W. M., 1992. Non-random pairing in American Kestrels: mate choice versus intra-sexual competition. Anim. Behav. 44: 811-821.

Brown, M. E., 1996. Assessing body condition in birds. Nolan, V., Jr. \& Ketterson, E. D., (eds) Current Ornithology vol. 13: 67-135. Plenum Press, New York.

Chastel, O., Weimerskirch, H. \& Jouventin, P., 1995. Body condition and seabird reproductive performance: a study of three petrel species. Ecology 76: 2240-2246.

Cherel, Y., Charrassin, J-B. \& Handrich, Y., 1993. Comparison of body reserve buidup in prefasting chicks and adults King Penguins ( Aptenodytes patagonicus). Physiol. Zool. 66: 750-770.

Cherel, Y., Robin, J. P. \& Le Maho, Y., 1988 Physiology and biochemistry of long-term fasting in birds. Can. J. Zool. 66: 159-166.

Erikstad, K. E., Asheim, M., Fauchald, P., Dahlhaug, L. \& Tveraa, T., 1997. Adjustment of parental effort in the puffin; the roles of adult body condition and chick size. Behav. 
Ecol. Sociobiol. 40: 95-100.

Freeman, S. \& Jackson, W. M., 1990. Univariate metrics are not adequate to measure avian body size. Auk 107: 69-74.

Massemin, S., Groscolas, R. \& Handrich, Y., 1997. Body composition of the European Barn Owl during the nonbreeding period. Condor 99: 789-797.

McDonald, P., Edwards, R. E., Greenhalgh, J. F. D. \& Morgan, C. A., 1995. Animal Nutrition 5th ed. Longman Scientific \& Technical, Longan House.

Niizuma, Y., 1995 The breeding numbers of Leach's Storm-petrels and Slaty-backed Gulls in Daikoku Island. Mem. Kushiro City Mus. 19 : 15-18 (In Japanese with English abstract).

Niizuma, Y., Takahashi, A., Sawada, M. \& Watanuki, Y., 1998. Sexual dimorphism in external measurements of adult Leach's Stormpetrels breeding at Daikoku Island. J. Yamashina Inst. Ornithol. 30: 36-39.

Niizuma, Y., Takahashi, A. \& Watanuki, Y., 1999. Energy expenditure of Leach's Storm-petrels in artificial nestboxes. Jpn. J. Ornithol. 47: 4953.

Schmidt-Nielsen, K., 1990. Animal Physiology. 4th ed. Cambridge University Press, Cambridge.

Takahashi, A., Kuroki, M., Niizuma, Y. \& Watanuki, Y., 1999. Parental food provisioning is unrelated to manipulated offspring food demand in a nocturnal single-provisioning alcid, the Rhinoceros Auklet. J. Avian Biol. 30 : 486-490.

Tveraa, T., S_ther, B-E., Aanes, R. \& Erikstad, K. J., 1998. Regulation of food provisioning in the Antarctic Petrel; the importance of parental body condition and chick body mass. J. Anim. Ecol. 67: 699-704.

van der Meer, J. \& Piersma, T., 1994. Physiologically inspired regression model for estimating and predicting nutrient stores and their composition in birds. Physiol. Zool. 67: 305-329.

(Received 28 July 2000; Accepted 23 October 2000) 


\title{
コシジロウミツバメにおける外部計測からの栄養状態の評価法
}

(A Body Condition Index Based on Body Mass and External Measurements of Live Leach's Storm-petrels. 49: 131-137)

\author{
新妻靖章 ${ }^{1 *}$ ・ 高橋晃周 ${ }^{2 * *}$ ・ 時田昇臣 ${ }^{3}$ ・羽山伸一 ${ }^{4}$ \\ 1 北海道大学農学部応用動物学教室 $\overline{\mathbf{T}} 060-8589$ 札幌市北区北 9 西 9 \\ 北海道大学低温科学研究所 $\mathbf{0} 060-0819$ 札幌市北区北19西 8 \\ 2 北海道大学理学部生物科学科厚岸臨海実験所 テ088-1113 厚岸郡厚岸町アイカップ \\ 3 日本獣医畜産大学動物栄養学教室 ₹180-8602 東京都武蔵野市境南町1-7-1 \\ 4 日本獣医畜産大学野生動物学教室 ₹180-8602 東京都武蔵野市境南町1-7-1
}

コシジロウミッバメ（Oceanodroma leucorhoa）を 用いて, 翼長, 最大尾長, 最小尾長, フショ長, 嘴高, 嘴長の外部計測値之体重から, 栄養状態の推定する指 標を作成した. 6 個所の外部計測值から主成分分析に よって抽出された第一主成分得点を計算することによっ て, 全体の体サイズを表す指標とした，第一主成分得 点を独立変数, 体重の 3 乗根を従属変数とし, 単回㷌 分析を行い, 回帰直線加残差を栄養状態の指標とし た. 本研究では，この指標を余剩栄養指標 (residual body condition index) と呼ぶ.コシジロウミッバメ
を用いて，余剩栄養指標の有効性を実測された脂肪蓄 積量と比較することで検討した。コシジロウミッバメ を全身麻醉下で殺した後, 死体からエチルエーテルに よって蓄積脂肪を抽出した. 余剩栄養指標は, 脂肪量 の 3 乗根の $57.4 \%$ を説明することが可能であった。 し たがった, 体重と外部形態の測定を行うだけで, 野外 で繁殖するコシジロウミッバメについて，鳥を犠牲に することなくまた容易に，栄養状態を推定することが 可能となった. 